\title{
Stress Evolution Law of Surrounding Rock with Gob-Side Entry Retaining by Roof Cutting and Pressure Release in Composite Roof
}

\author{
Yong Zhang, ${ }^{1,2}$ Huichen Xu $\mathbb{D}^{3},{ }^{3}$ Peng Song, ${ }^{4}$ Xiaoming Sun $\mathbb{D}^{1},{ }^{1}$ Manchao He, ${ }^{1}$ \\ and Zhibiao Guo ${ }^{1,2}$ \\ ${ }^{1}$ State Key Laboratory for Geomechanics and Deep Underground Engineering, \\ China University of Mining \& Technology (Beijing), Beijing 100083, China \\ ${ }^{2}$ School of Mechanics and Civil Engineering, China University of Mining \& Technology (Beijing), Beijing 100083, China \\ ${ }^{3}$ College of Mechanical and Architectural Engineering, Taishan University, Tai'an, Shandong 271000, China \\ ${ }^{4}$ Department of Civil Engineering, Nanyang Institute of Technology, Nanyang, Henan 473004, China
}

Correspondence should be addressed to Huichen Xu; xhccumtb@163.com and Xiaoming Sun; sunxiaoming@cumtb.edu.cn

Received 19 April 2020; Revised 10 June 2020; Accepted 30 June 2020; Published 13 August 2020

Academic Editor: Georgios I. Giannopoulos

Copyright (c) 2020 Yong Zhang et al. This is an open access article distributed under the Creative Commons Attribution License, which permits unrestricted use, distribution, and reproduction in any medium, provided the original work is properly cited.

\begin{abstract}
The stress concentration of gob-side entry surrounding rock is a hot topic in coal mining. In this paper, through theoretical analysis and numerical simulation, the pressure relief mechanism of the gob-side entry retaining by roof cutting and pressure release (RCPR) and the spatiotemporal development law of surrounding rock stress of the gob-side entry were analyzed. The studies showed that the gob-side entry retaining by RCPR shortened the length of the lateral cantilever by directional roof cutting, which weakened the stress level of the gob-side entry. In the meantime, the goaf gangues could play a good filling role by using their breaking and swelling characteristics under the action of gangue-blocking supports and further optimized the stress environment along the roadway. Field industrial tests verified that the gob-side entry retaining by RCPR had a significant effect on pressure relief, and the surrounding rock stress and deformation tended to stabilize after about $160 \mathrm{~m}$ of lagging working face. Numerical analysis reproduced the whole process of "mining-retention-using" of roof cutting roadway and revealed that surrounding rocks were always in the zone of relative stress reduction during the whole process. The peak value of mining-induced lateral stress was about $10 \mathrm{~m}$ away from the middle point of the gob-side entry. The change of surrounding rock stress could be divided into three stages: significant increase, dynamic adjustment, and stable stage. However, during the second mining, the stress connected zone would appear on the leading working face, and the stress concentration in this zone was significant. Based on the above analysis, we concluded that the new technology could be applied to the medium-thickness coal seam in the composite roof.
\end{abstract}

\section{Introduction}

Gob-side entry retaining (GSER) has significant technical and economic advantages in improving the recovery rate of resources [1], easing the mining and replacement tension, realizing Y-type ventilation [2], and so on. However, the gob-side entry is a special type of entry that is substantially affected by the mining activity during construction [3]. Due to the problems of overburden movement, mining stress transfer, and surrounding rock stability structure [4-6], the stability control of such a roadway is one of the most difficult problems in coal mining. Therefore, to ensure the stability of surrounding rock is a key prerequisite for the successful application of GSER.

Generally speaking, the stress of surrounding rocks of the gob-side entry is mainly caused by the movement of overlying strata. Many experts did a lot of useful research on the overburden movement and stability control of the gobside entry [7]. Bai et al. [8, 9] built a roof structure model, analyzed the mechanical process of roof bending deformation and failure, and proposed three technical measures of fully mechanized caving roadway excavation along the gob: setting up reasonable coal pillars, optimizing mining layout, and dynamic phased control technology. Han et al. 
$[10,11]$ studied the relationship between the length of lateral cantilever and roadway pressure and suggested the optimum length of the lateral cantilever under gob-side retaining roadway with hard roof. Yang et al. $[12,13]$ proposed that the surrounding rock structure and stress level of the gobside entry can be optimized effectively by changing the support angle and pretension of the bolt. Li et al. [14] proposed that the stability of the roadway surrounding rock can be improved by presplitting the roof in a reasonable position. Wang et al. [15] established a short cantilever beam mechanical model and solved using energy theory and displacement variational methods.

The above study indicates that by changing the stability structure of the surrounding rock, the stress level of the surrounding rock can be optimized and the stability of surrounding rock can be improved $[16,17]$. He et al. proposed an innovative GSER $[18,19]$. This technology optimizes the surrounding rock structure through the directional cutting roof, strengthens the surrounding rock with constant resistance and large deformation supporting (CRLDS) [20, 21], and forms roadway automatically by goaf gangue and gangue-blocking supports. Compared with the traditional GSER, this technology eliminates the filling wall, and the mining arrangement comparison is shown in Figure 1.

The GSER by RCPR has been applied in many mining areas in China. Previous studies shown that after adopting this technique, the super pressure value of the gob-side entry decreased, the influence range was small, and the surrounding rock stress area was stable after a certain lag distance [22-24]. And, most of the existing researches focused on the evolution of roof structure and its control technology, but few on the spatiotemporal evolution of stress for the gob-side entry surrounding rock. The GSER by RCPR is different from the traditional goaf mining technology. This technology realized the structure optimization of the roof near the cut side of the stope and fully utilized the fragmentation and expansion of the goaf, slowed the final settlement of the basic roof of rock beam, weakened the magnitude of the stress transfer to the lateral stress in the mined-out area, which led to the stability of the roadway higher than the traditional goaf mining technology.

In this study, the pressure relief mechanism of the technology and the spatiotemporal evolution law of surrounding rock stress were mainly studied. At the same time, an engineering example was given and the reliability of the technology was verified by numerical analysis.

\section{Gob-Side Entry Retaining by RCPR}

The GSER by RCPR is based on the "Cut-roof Broken Arm Beam" theory [23]. Its technical core lies in the optimization of the roadway roof structure and the application of CRLDS. The technical principle is summarized as follows.

Firstly, the working face is designed as the GSER requirement. CRLDS technology is applied to the support design of the reserved roadway. Before the working face mining, bilateral cumulative tensile explosion (BCTE) technology [24] is used for the directional cutting roof. The weak structural surface is created by this method, and its length is consistent with that of the stope roadway. The existence of a weak structural surface ensures the collapse of gangue in a fast and timely manner. BCTE and the CRLDS technology can maximize the integrity of the roof strata, and it can change the group of the moving rock stratum in the roadway stope side roof. In particular, some parts of the basic roof are converted to the direct roof with the adoption of RCPR, which increases the thickness of the rock mass in the caving zone.

After the mining face is recovered, the "Cut-roof Broken Arm Beam" is formed rapidly under the effect of mine pressure, which consists of a direct roof and part of the basic roof. The caved gangue fills gob with its own breaking and swelling characteristics and quickly forms the supporting structure for the first movement of the rock beam of the basic roof. When the basic roof breaks and sinks, its breaking position is usually located on the suture line side. The rock blocks will form a plastic hinge structure by the moving rock beam, and continue to transfer the force to the mine around. Compared to traditional mining technology, the gangue contacts point in gob will move forward and the given amount of deformation and breaking angle will be reduced, thereby weakening the load acting on the top of the roadway.

The stability of gob-side entry will be improved with the protective effect of the "Cut-roof Broken Arm Beam," the integrated coal beside the roadway, and the filling effect of the gangue. With the continuous advance of the working face, the pressure of the roadway becomes stable gradually.

Figure 2 shows the pressure release mechanism of the GSER by RCPR.

\section{Mechanical Structure Model of Surrounding Rock}

The stress on the surrounding rock depends on the movement of the key strata on the roof. Therefore, the statically indeterminate beam structure theory in structural mechanics is adopted to construct structural mechanics models of the traditional GSER and the GSER by RCPR, respectively; the magnitude of roadway support resistance is analyzed emphatically, so as to make a comparative analysis of the two methods.

In general, the lower strata are in the state of "given deformation" $[25,27]$ in the process of breaking, turning, and sinking of the key block of the basic roof; the lateral stress peaks of gob is mainly borne by solid coal, while the bearing structure of roadway mainly bears the direct roof over the roadway that does not collapse, as well as the load of key block B during fracture, rotation, and finally the gangue. Therefore, the establishment of a simplified mechanical model along the goaf (as shown in Figure 3 ) requires the following assumptions:

(1) After mining, the horizontal thrust of rocks A and C is equal to that of rock $\mathrm{B}\left(T_{a}=T_{c}\right)$ and the operating point is located in the middle of the contact surface $(s / 2)$.

(2) The elastoplastic demarcation point of the basic roof is also the fracture location of the key rock $\mathrm{B}$ on the 


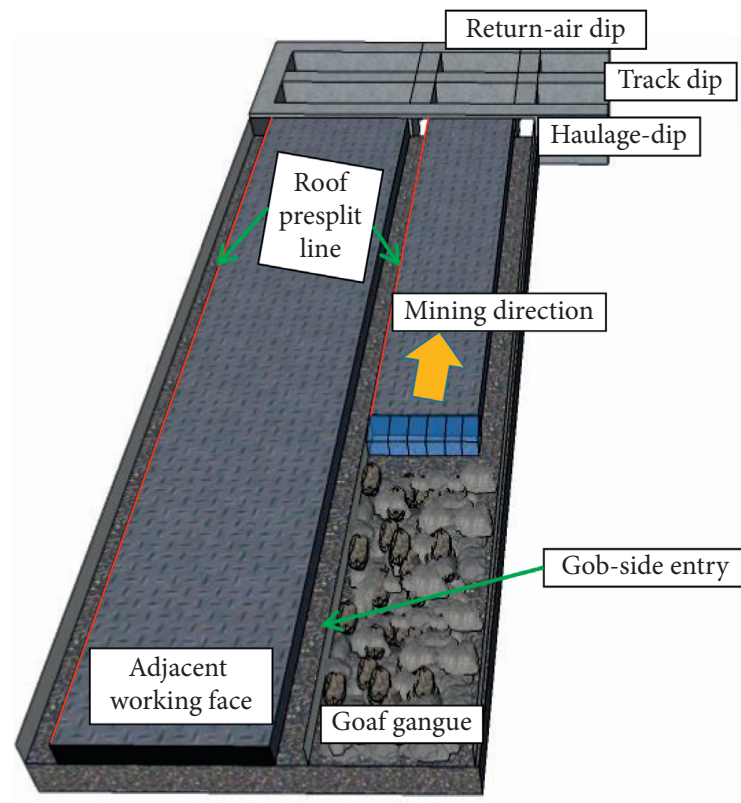

(a)

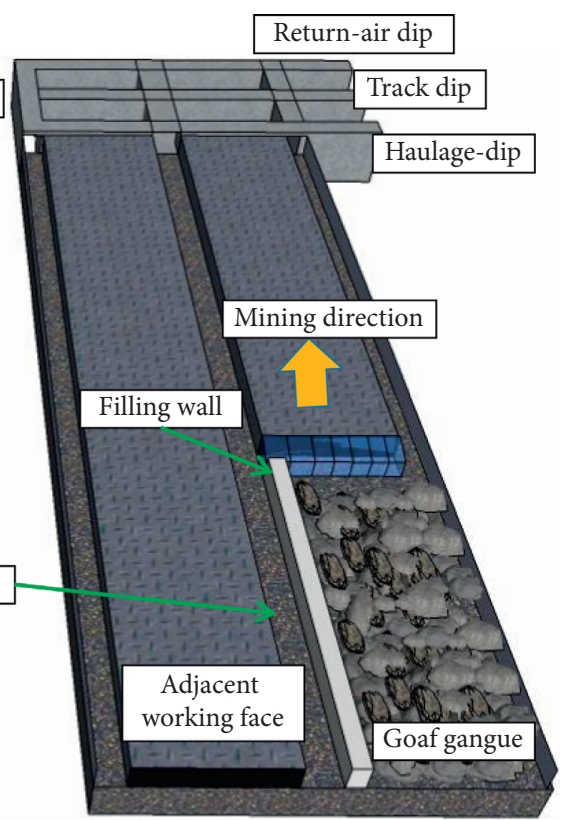

(b)

FIGURE 1: Comparison of mining layout: (a) the GSER by RCPR; (b) the traditional GSER with filling wall.

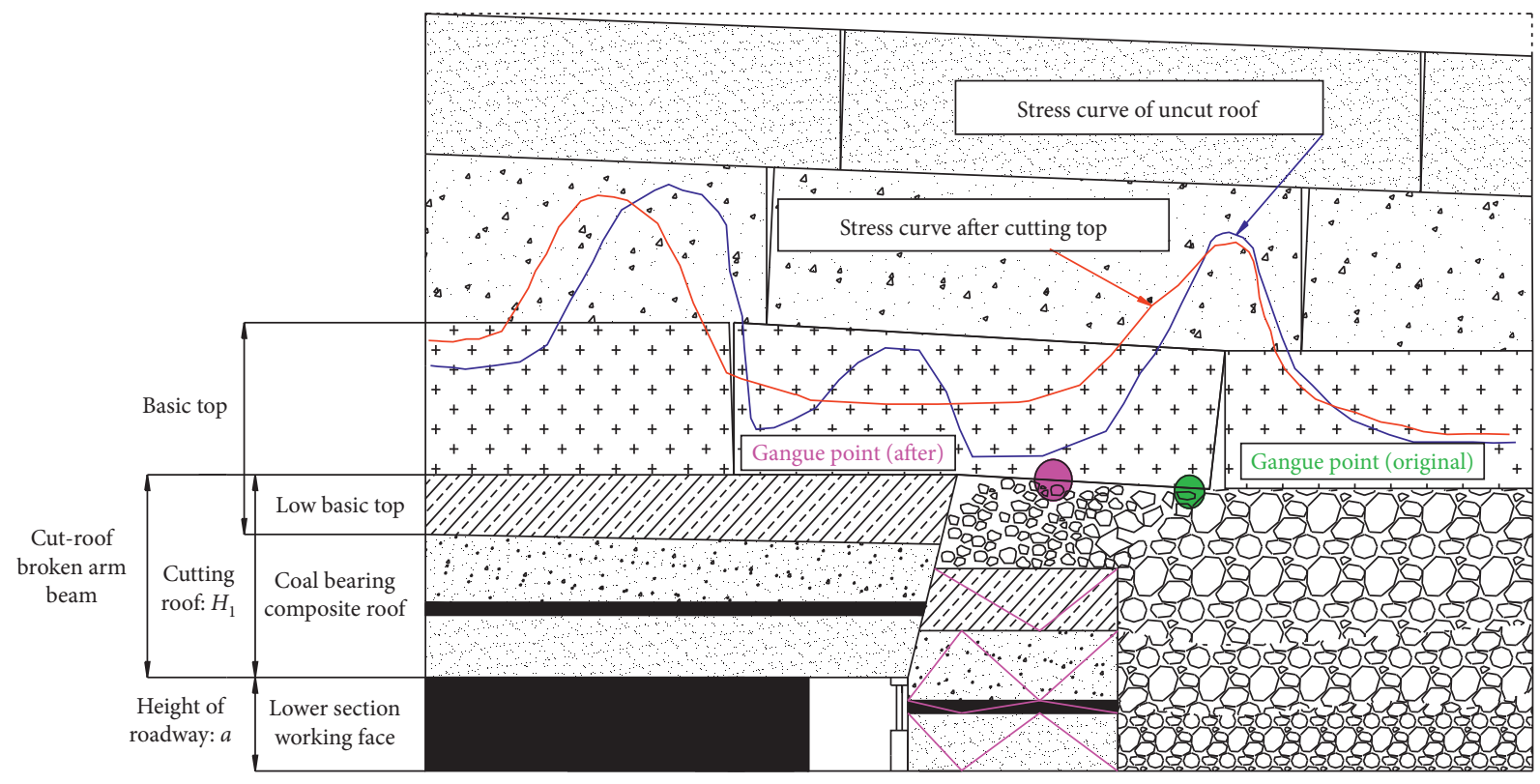

FIgURE 2: Technical principle diagram of the GSER by RCPR.

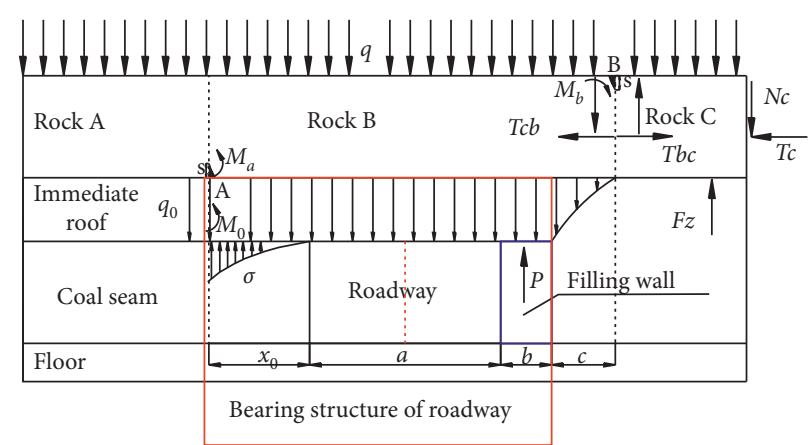

FIGURE 3: Simplified mechanical model of the traditional GSER. 
solid coal side, and the key block B bends and sinks to the side of gob along this point.

(3) The filling wall can timely control the bending subsidence of rock $\mathrm{B}$, and the masonry beam structure of key rocks $\mathrm{B}$ and $\mathrm{C}$ can be stable. The supporting force of the gangue on key rock B is ignored.

(4) The shear stress between the immediate roof, basic roof, and upper strata is neglected.

(5) The load of the overburden layer on the basic roof is uniformly distributed on the key block of the basic roof.

(6) The influence of the support in the roadway is ignored.

After mining on the working face, the elastic and plastic junction point $x_{0}$ will be formed on the solid coal side of the roadway, and it will be determined by the fracture location of the basic roof rock block (namely rock B) in the solid coal. The distance between the break point and the side of the roadway may be given as follows [10]:

$$
x_{0}=\frac{h_{d} \lambda}{2 \tan \varphi_{0}} \ln \left(\frac{k \gamma H+\left(c_{0} / \tan \varphi_{0}\right)}{\left(c_{0} / \tan \varphi_{0}\right)+\left(P_{x} / \lambda\right)}\right) .
$$

The support force provided by solid coal can be written as follows:

$$
\sigma=\left(\frac{C_{0}}{\tan \varphi_{0}}+P_{x}\right) \exp \frac{2 \tan \varphi_{0}}{M \lambda} x-\frac{C_{0}}{\tan \varphi_{0}} .
$$

The fracture length of key rock B can be written as follows [28]:

$$
L_{i}=l\left(-\frac{l}{S}+\sqrt{\frac{l^{2}}{S^{2}}+\frac{3}{2}}\right) .
$$

The strength of the roadway can be expressed by the supporting resistance of roadway side $(P)$. The horizontal thrust received by the key block $B$ can be shown by the following equation:

$$
T_{b}=\frac{q^{\prime} L}{2\left(h-\Delta S_{b}\right)} .
$$

The relationship between the settlement and the fracture length can be determined geometrically by the following equation [28]:

$$
\Delta S_{b}=L \sin \theta_{1}
$$

As shown in Figure 3, a static equilibrium method is adopted to conduct the mechanical analysis of the basic top rock block.

(i) Rock C:

$$
\begin{aligned}
\left\{\begin{array} { l } 
{ \sum F _ { x } = 0 , } \\
{ \sum F _ { y } = 0 , }
\end{array} \Longrightarrow \left\{\begin{array}{l}
N_{b}=q L+N_{c}, \\
T_{c}=T_{b},
\end{array}\right.\right. \\
\sum M_{B}=0 \Longrightarrow \frac{M_{b}+T_{c}\left(\left(\Delta S_{c}+s\right) / 2\right)-N_{c} L-q L^{2}}{2}=0, \\
N_{b}=\frac{\left(M_{b}+T_{c}\left(\left(\Delta S_{c}+s\right) / 2\right)+q L^{2}\right) / 2}{l} .
\end{aligned}
$$

(ii) Rock B:

$$
\begin{gathered}
\sum M_{A}=0 \\
M_{a}+P_{x}\left(\frac{x_{0}+a+b}{2}\right)+T_{b}\left(h-\Delta S_{b}\right) \\
+\int_{0}^{x_{0}} \sigma\left(x_{0}-x\right) \mathrm{d} x+\frac{M_{0}-M_{b}-q L^{2}}{2} \\
-\frac{q_{0}\left(x_{0}+a+b\right)^{2}}{2}-N_{b} L=0 .
\end{gathered}
$$

Combined with the above analysis and combined equations (1)-(9), the calculation formula of side support can be expressed by the following equation:

$$
P_{x}=\frac{\left[\left(\left(2 M_{b}+q L^{2}+q_{0}\left(x_{0}+a+b\right)^{2}\right) / 2\right)+\left(q^{\prime} L\left(\Delta S_{c}-3 s / 4\right) / 2\left(h-\Delta S_{b}\right)\right)-M_{a}-M_{0}-\int_{0}^{x_{0}} \sigma\left(x_{0}-x\right) \mathrm{d} x\right]}{\left(x_{0}+a+b\right) / 2},
$$

where $T_{C}$ is the lateral horizontal thrust received by rock $\mathrm{C}$, $\mathrm{kN}$; the shear stress of rock B and C can be expressed by $N_{b}$ and $N_{c}, \mathrm{kN} ; q^{\prime}$ is the load set of the basic roof, $\mathrm{kN} / \mathrm{m} ; q_{0}$ is the average load of the direct roof $\mathrm{kN} / \mathrm{m} ; \Delta S_{c}$ to rock the sink of the rock $\mathrm{C}, \mathrm{m} ; M_{a}$ and $M_{b}$ are the residual bending moments of rocks $\mathrm{A}$ and $\mathrm{B}, \mathrm{kN} \cdot \mathrm{m} ; M_{0}$ is the bending moment of the direct roof jacking against the basic roof, $\mathrm{kN} \cdot \mathrm{m} ; P_{x}$ provides support resistance for roadway side support, $\mathrm{kN}$; $a$ is the width of the roadway, $\mathrm{m} ; b$ is the width of filling wall, $\mathrm{m}$; and $S$ is the vertical length of the contact surface of plastic hinge between the blocks, m.

According to the comprehensive analysis of Figure 3 and equation (11), it can be seen that the length of key rock B $(L)$ has the following relations with the cantilever length of the 
immediate roof outside the backfill $(c)$, the width of the limit equilibrium zone of lateral coal body $\left(x_{0}\right)$, the width of roadway $(a)$, and the width of filling wall $(b)$ :

$$
L=x_{0}+a+b+c .
$$

When we adopt the RCPR technology, the structural mechanical model along the roadway is as shown in Figure 4. By this time, $L^{\prime}$ can be written as follows:

$$
L^{\prime}=x_{0}^{\prime}+a+c^{\prime} \text {. }
$$

By a contrastive analysis of (12) and (13), the smaller cantilever length of the immediate roof weakens the supporting resistance required. Therefore, the pressure acting on the gob-side entry decreases.

The above analysis indicates that the decrease of support resistance in the roadway directly reflects the decrease of stress acting on the roadway. As a result, the GSER by RCPR can relieve the surrounding rock stress environment to a certain extent, compared with the traditional GSER.

\section{Case Study: Halagou Coal Mine}

Theoretical analysis indicates that the brevity of the lateral cantilever beam can effectively alleviate the stress concentration in the gob roadway. However, in order to deeply analyze the temporal and spatial development law of the surrounding rock stress field and displacement field in the gob-side entry under the application of the GSER by RCPR, it can better guide the field engineering practice. Therefore, with the 12201 working face of $\mathrm{Ha}$ Lagou Coal Mine as the engineering background, the stress development law of the whole cycle of surrounding rock of gob-side entry was analyzed by numerical analysis method.

4.1. Engineering Geological Condition. Ha Lagou Coal Mine in Shen Dong mining area is located in the northwest of $\mathrm{Yu}$ Lin city, Shanxi Province, China, as shown in Figure 5. Its complex geological structure is divided into a moderate degree and the actual exploration area is $85 \mathrm{~km}^{2}$. The eastern and western parts of Ha Lagou Coal Mine are $8.4-11 \mathrm{~km}$ and $8.3-10 \mathrm{~km}$, respectively, and eight layers of near-horizontal coal seam can be collected and are partially recoverable, which are 1-2 ${ }^{u}$ coal, 1-2 coal, 2-2 coal, 3-1 coal, 4-2 coal, 4-3 coal, 5-2 coal, and 5-2u coal. The geosphere shows a monoclinic structure that tends to be SW, with little change in formation height and less than $1^{\circ}$ in the dip angle, which is generally located in the stable syncline of Ordos, China.

The 12201 fully mechanized coals mining working face is the first mining working face in the second section of 1-2 coal in Halagou Coal Mine. The coal seam is buried at a depth of $60-100 \mathrm{~m}$. The working face length is $320 \mathrm{~m}$. The industrial test section length is $580 \mathrm{~m}$, which is located in 12201 transport roadway. This coal working face thickness is $1.6-2.4 \mathrm{~m}$. The working face average mining height is $2 \mathrm{~m}$, and the recovery coal volume is 610 thousand tons; in general, the coal seam is relatively stable.

The mining layout of the 12201 working face is shown in Figure 6(a). The lithologic characteristics of the working face

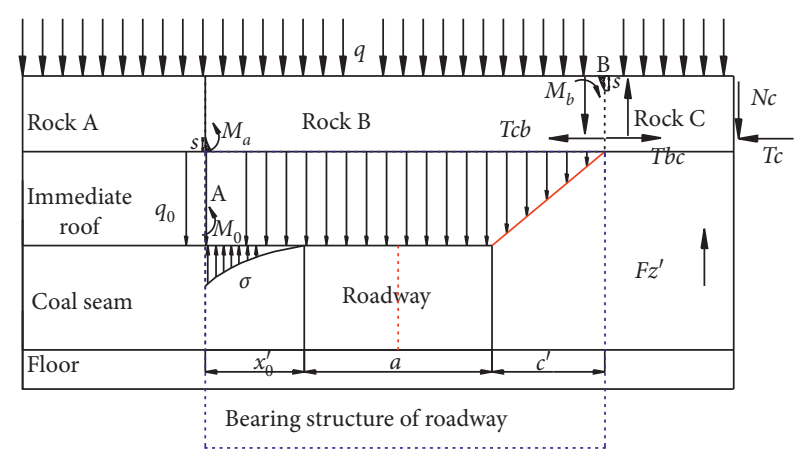

FIgURE 4: Simplified mechanical model of the GSER by RCPR.

are shown in Figure 6(b). According to the calculation formula, $\sigma_{v}=\gamma h$, it is estimated that the self-weight stress suffered by the research roadway is $1.375-1.75 \mathrm{MPa}$, the bulk density of rock mass is calculated as $\gamma=25 \mathrm{kN} / \mathrm{m}^{3}$, and the 12201 transport roadway depth is $55-70 \mathrm{~m}$. Through the field geological survey and analysis of regional stress structure, there is a certain residual horizontal tectonic stress in this area; however, the horizontal tectonic stress is very small. Therefore, this paper only considers the effect of self-weight stress during the study.

4.2. Support Design for Roadway. The 12201 working face is arranged in the second panel coal seam of the 1-2 east wings. The height and width of the 12201 transportation roadway are $2.5 \mathrm{~m}$ and $5.4 \mathrm{~m}$, respectively, with a section area of $12.96 \mathrm{~m}^{2}$ and a strike length of $766.6 \mathrm{~m}$.

The original support of the test roadway was supported by anchor net and cable. In order to make sure that the roadway can withstand multiple deformations of surrounding rock without loss of stability, the roadway is reinforced by constant resistance and large deformation anchor cable (CRLDAC). Lacy beam and single hydraulic support were used as temporary support to ensure the roadway stable under the influence of dynamic pressure. The "steel mesh $+i$-steel + single hydraulic prop" was used as gangue-blocking supports to prevent gangue from pouring into the roadway while gangue forms the roadway side.

The depth of the directional cutting roof in the test roadway is $6.5 \mathrm{~m}$, and the precrack angle is $15^{\circ}$ (the included angle with the plumb line of the roof). The detailed support design is shown in Figure 7.

\section{Numerical Analysis}

5.1. Numerical Modeling Process. According to the above analysis and working face geological conditions, the numerical model was established by FLAC3D. The model size is $150 \times 225.6 \times 60 \mathrm{~m}$ (length $\times$ width $\times$ height), which is divided into 1052400 units and 1091137 nodes. To explain the problem more clearly, mesh refinement and a Mohr-Coulomb constitutive model is used. The load on the upper boundary of this selection is $q=0.92 \mathrm{MPa}\left(\gamma=25 \mathrm{k} \cdot \mathrm{N} / \mathrm{m}^{3}\right)$. The size of the 12201 transportation roadway is $5.2 \mathrm{~m} \times 2.2 \mathrm{~m}$ (wide $\times$ high); Figure 8 shows schematic of 


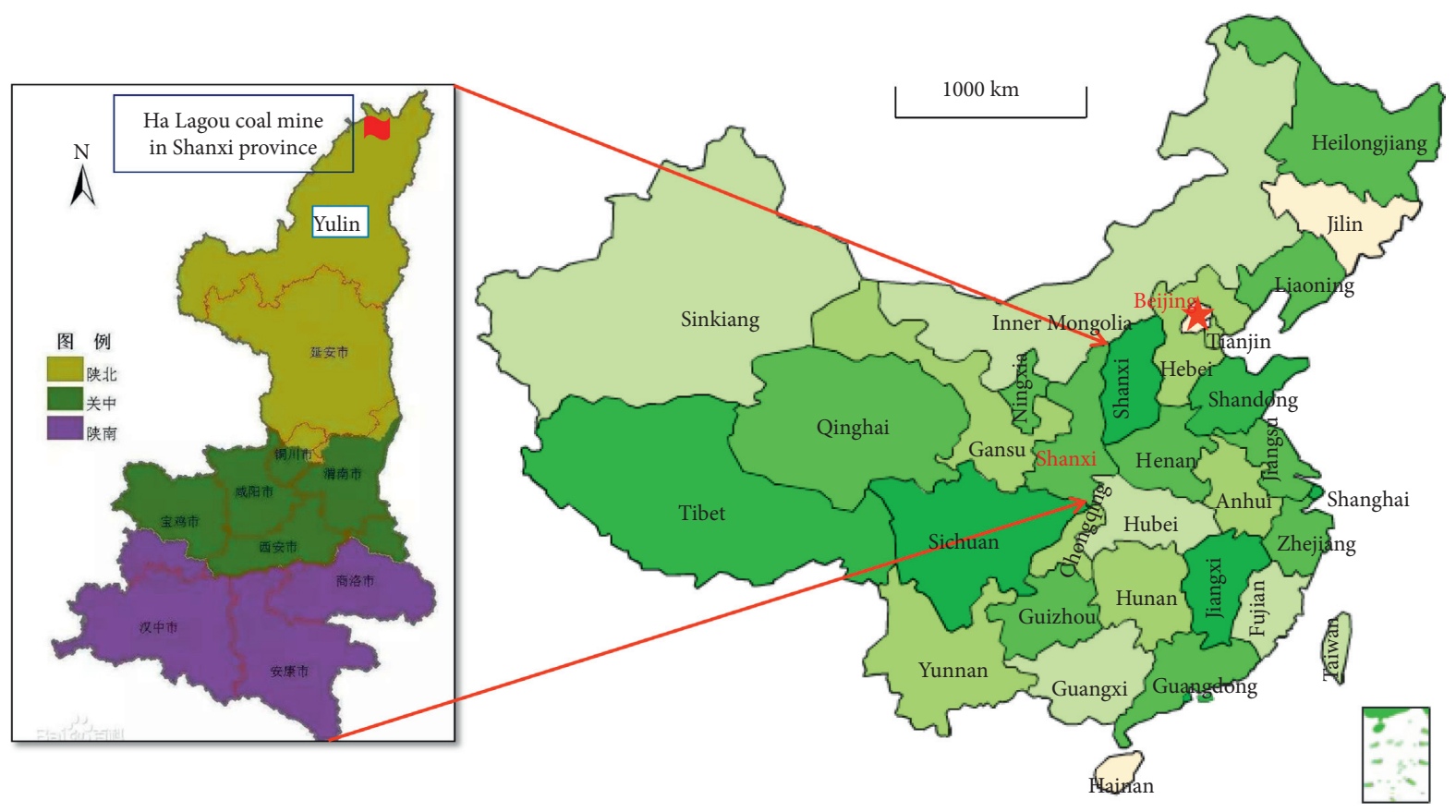

Figure 5: Location of Ha Lagou coal mine in Shanxi Province.

mining layout, respectively. Table 1 displays the mechanical parameters of the surrounding rock. The height of the 12201 working face is $2 \mathrm{~m}$. The height of the cutting roof is $h_{c}=6.5 \mathrm{~m}$ :

$$
h_{c}=\frac{h}{K_{c}-1},
$$

where $h_{c}$ is the height of the cutting roof and $K_{c}$ is the coefficient of broken up, 1.2-1.35, generally.

To study the effect of cutting angle on the lateral supporting pressure of roadway during the mining process, $10^{\circ}$, $15^{\circ}$, and $30^{\circ}$ were selected for comparison on the basis of determining the above-mentioned cutting height of $6.5 \mathrm{~m}$.

As can be seen from Figure 9, under this parameter, the leading stress has the least influence on the roadway. Therefore, the optimal design parameters are $6.5 \mathrm{~m}$ (the height of the cutting roof) and $15^{\circ}$ (the cutting angle).

\subsection{Numerical Simulation Result Analysis}

5.2.1. Stress Evolution Law of Surrounding Rock during Excavation. The dynamic distributions of the vertical stress of the 12201 transportation roadway in $20 \mathrm{~m}, 40 \mathrm{~m}, 80 \mathrm{~m}$, and $120 \mathrm{~m}$ are selected, respectively. With the progress of excavation, the range of vertical stress concentration and the concentration factor will change continuously.

In Figure 10, vertical stress field during the distribution was shown. The stress concentration peaks present a U-shaped feature, which appears at about $5-10 \mathrm{~m}$ on both sides of the roadway and about $3 \mathrm{~m}$ ahead of the heading face. The stress concentration factor is about 1.38.

Simulation results show that the coal and surrounding rock within the stress concentration range is affected by the concentrated stress. The integrity of the coal and surrounding rock structure is bound to be destroyed.

\subsubsection{Stress Distribution of Retreating in the Upper Mining} Panel. Due to the influence of excavation disturbance, the stress environment of engineering rock mass has changed. However, the stress of the surrounding rock is redistributed and balanced in a wide range of mining space before the working face excavation.

This simulation focused on the observation of dynamic characteristics of mining stress and stress stacking position at a concentrated profile. In the mining process of the working face, the distributed excavation method is adopted, every $10 \mathrm{~m}$, and it is calculated to balance. Then, the dynamic distribution characteristics of the vertical stress field are analyzed.

The numerical simulation results are shown in Figure 11. The lateral stress concentration range is about $5-30 \mathrm{~m}$ away from the roadway, and then, it decreases gradually to the original rock stress level. The roof of the roadway is always in the pressure relief area owing to the effect of the RCPR. The influence range of the advance stress of the working face is about $15 \mathrm{~m}$. The coefficient of stress concentration is 1.23 . As the roof of the stope moves periodically, the roof pressure of the roadway presents the characteristic of periodic change. The dynamic adjustment range of the roadway roof pressure is about $10-30 \mathrm{~m}$ each time. After working face mining for $80 \mathrm{~m}$, the roof pressure gradually tends to be stable.

For further analysis of the vertical stress variation around the working face, we set up a monitoring line to work the mining face at every $5 \mathrm{~m}$ away from the side of roadway, $10 \mathrm{~m}$ left, $15 \mathrm{~m}$ left, and $5 \mathrm{~m}$ right. In addition, a monitoring line is arranged along the slope at the position of the working 


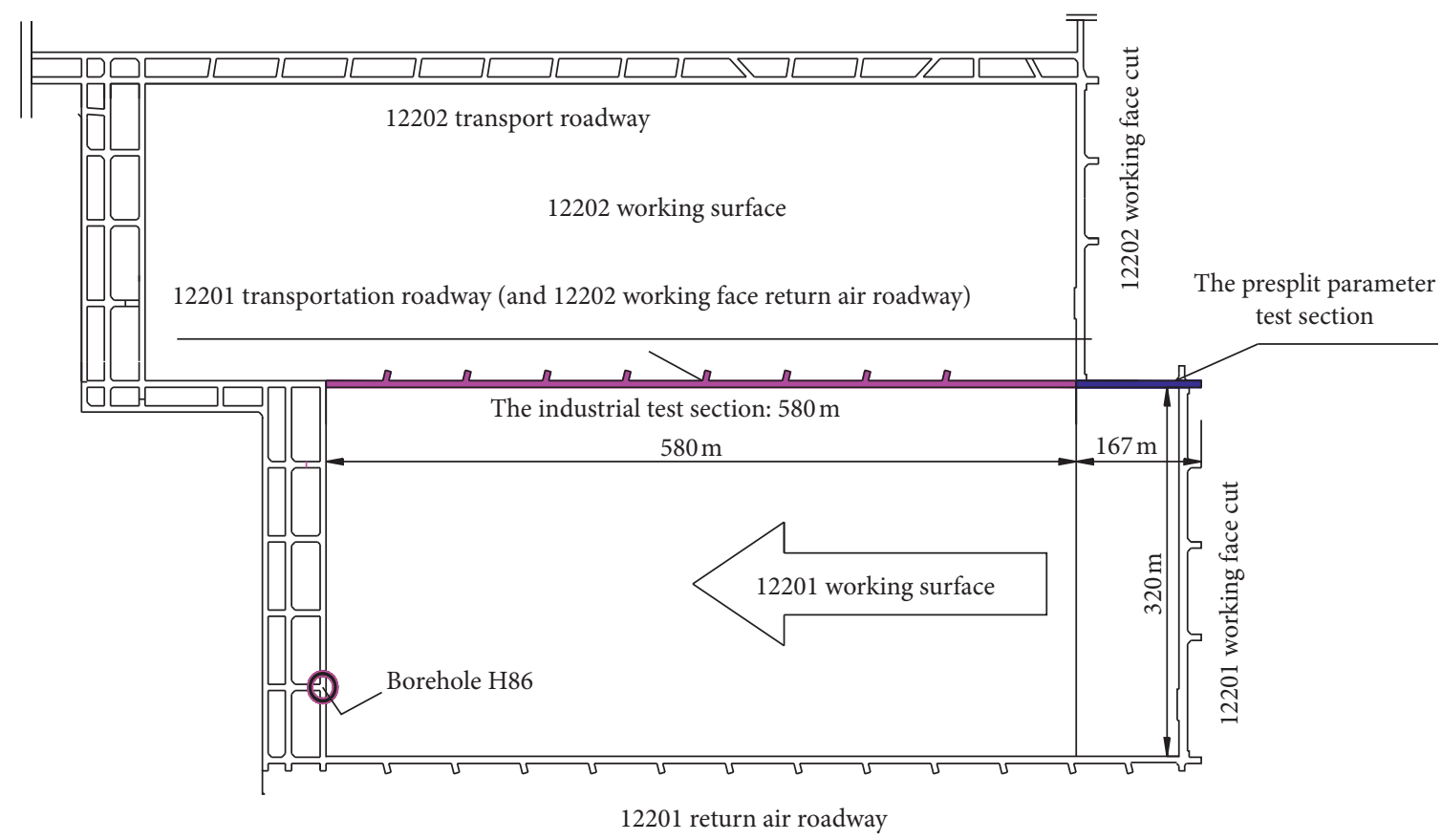

(a)

\begin{tabular}{|c|c|c|c|}
\hline Description of Lithology & Columnar & Lithology & $\begin{array}{l}\text { Seam } \\
\text { thickness }(m)\end{array}$ \\
\hline $\begin{array}{l}\text { Gray, with fossilized plant } \\
\text { leaves and pyrite nodules }\end{array}$ & & \multirow{2}{*}{ Siltstone } & \multirow{2}{*}{4.05} \\
\hline $\begin{array}{l}\text { Gray, argillaceous cementation, } \\
\text { horizontal bedding, thin bedded siltstone. }\end{array}$ & & & \\
\hline \multirow{2}{*}{$\begin{array}{l}\text { Gray, argillaceous cementation, near horizontal bedding } \\
\text { development, local sandwiched thin layer of sandstone. }\end{array}$} & & $\begin{array}{l}\text { Fine-grained } \\
\text { Sandstone }\end{array}$ & 3.34 \\
\hline & & Mudstone & 1.35 \\
\hline $\begin{array}{l}\text { Semidark type is the main, } \\
\text { the second for dim and semibright coal }\end{array}$ & & $1-2^{u}$ Coal & 1.56 \\
\hline $\begin{array}{l}\text { Gray, argillaceous cementation, near horizontal bedding } \\
\text { development, local sandwiched thin layer of sandstone }\end{array}$ & & $\begin{array}{l}\text { Siltstone } \\
1-2 \text { Coal }\end{array}$ & 1.84 \\
\hline $\begin{array}{l}\text { Semidark type is the main, } \\
\text { the second for dim and semibright coal }\end{array}$ & & \multirow{2}{*}{ Siltstone } & \multirow{2}{*}{3.67} \\
\hline $\begin{array}{l}\text { Livid, mainly feldspar, secondary quartz, containing mica, pyrite and } \\
\text { carbonized plant detrital fossils can be seen locally, horizontal bedding. }\end{array}$ & & & \\
\hline Gray, argillaceous cementation, horizontal bedding & & $\begin{array}{l}\text { Fine-grained } \\
\text { sandstone }\end{array}$ & 4.23 \\
\hline
\end{tabular}

(b)

FIGURE 6: Working face mining arrangement: (a) mining layout; (b) the lithologic characteristics of the working face.

face. The monitoring line layout is shown in Figure 8 (Lane 1-Lane 4) and the variation of stress is shown in Figure 12.

As shown in Figure 12(a), the stress value of the lanes $1-3$ is constantly changing beyond the working face of $30 \mathrm{~m}$. Besides, the stress values of the lines 1-3 are always increasing. After the distance from the working face is $60 \mathrm{~m}$, the stress values of the monitoring lines 1-3 tend to be stable.

The monitoring line 4 is right at the end of the cutting roof. The stress variations for lane 4 with the distance from the working face within a $35 \mathrm{~m}$ range of advance working face, the stress value increases continuously. The stress value suddenly decreases in the range of $25-35 \mathrm{~m}$ in the advanced working face, and it increases in the $25 \mathrm{~m}$ range of the advance working face. The change of stress value is due to the existence of the weak surface of the structure formed by the cutting roof. Therefore, we can think that the length (along the working face advancing direction) of the basic roof after the cutting roof is $25 \mathrm{~m}$. When the measured line lags the 


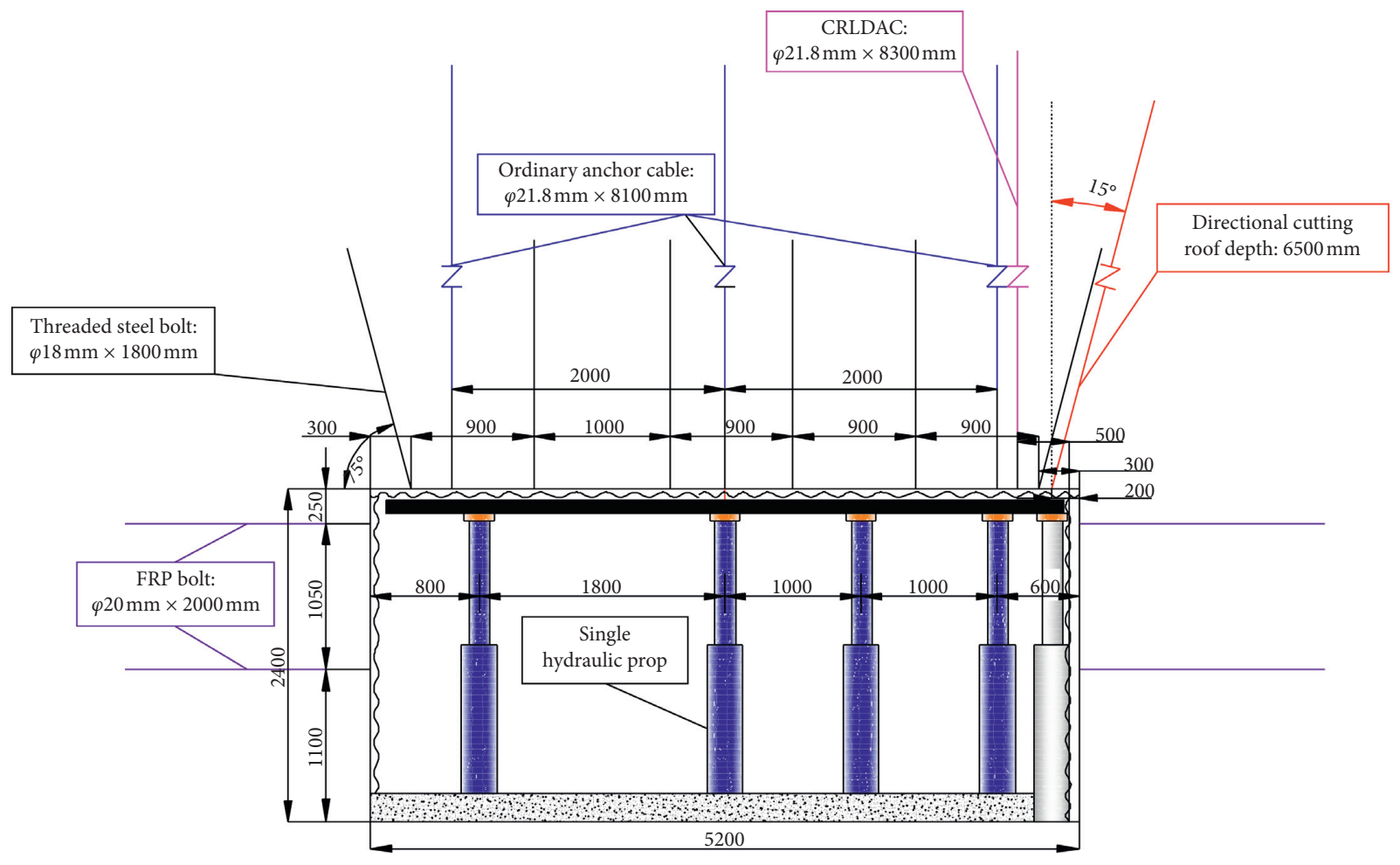

Figure 7: The support design section of 12201 transport roadway.

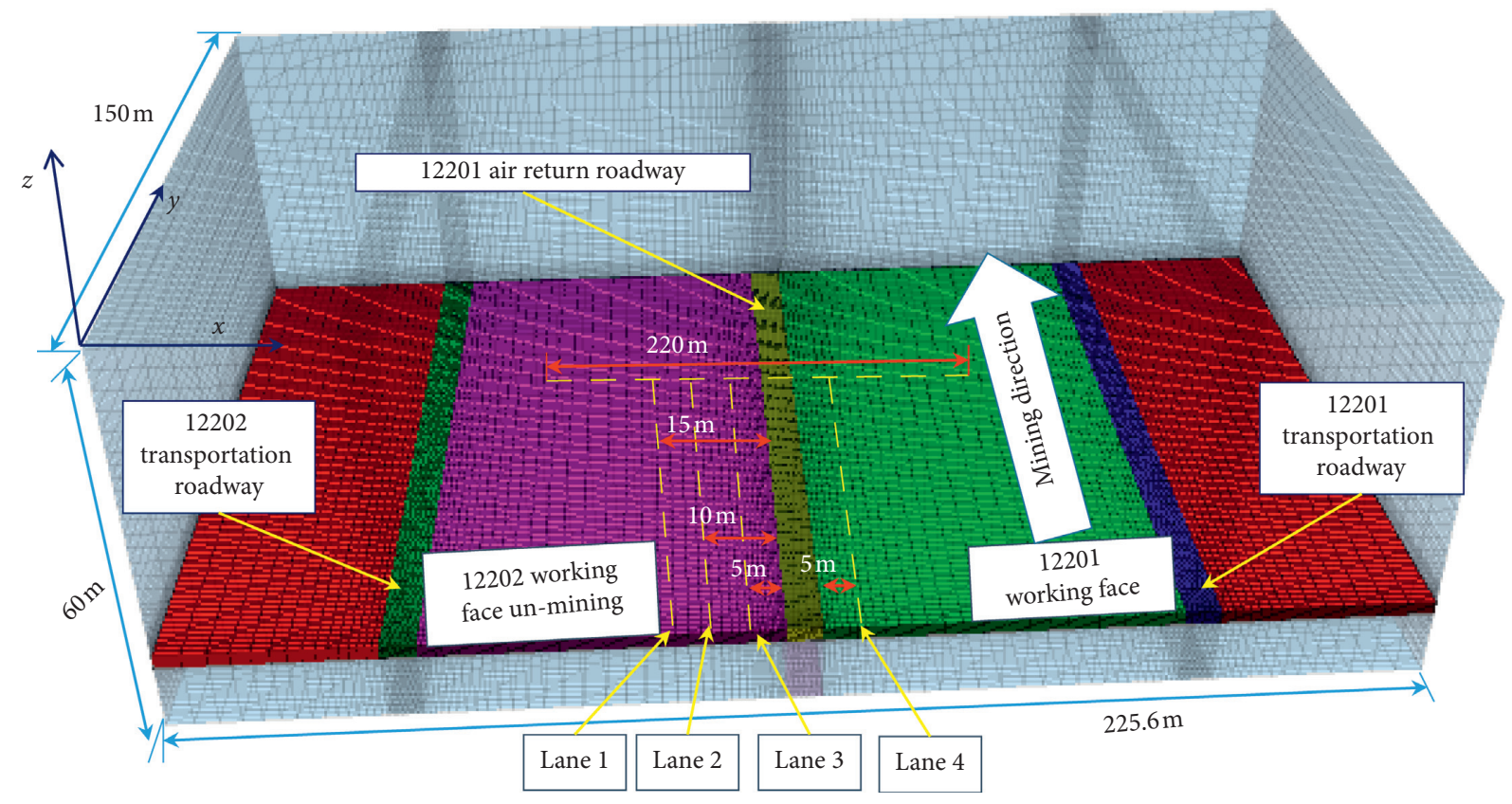

FIgURE 8: Schematic of mining model layout.

working face, the stress value decreases and tends to be stable. In addition, the stress value after stability is far less than the stress value of the next working face.

To better show the variation of stress in the orientation of the working face, we set monitoring line 5. The stress changes of monitoring curve 5 are shown in Figure 12(b). The stress value is minimum value in the central position of the retained roadway. The stress peak occurs $10 \mathrm{~m}$ from the roadway and is located within the next working face. The stress concentration factor is about 1.5. In addition, we can find that the surrounding rock of the gob-side entry is in the pressure relief area. In the meantime, the pressure on the stope is also decreased and increases at the remaining locations. 
TABLE 1: Mechanical parameters of surrounding rock.

\begin{tabular}{|c|c|c|c|c|c|c|c|c|}
\hline Position & Rock stratum & $\begin{array}{c}\text { Thickness } \\
(\mathrm{m})\end{array}$ & $\begin{array}{c}\text { Shear } \\
\text { modulus } \\
(\mathrm{GPa})\end{array}$ & $\begin{array}{l}\text { Bulk modulus } \\
\qquad(\mathrm{GPa})\end{array}$ & $\begin{array}{l}\text { Cohesive force } \\
\qquad(\mathrm{MPa})\end{array}$ & $\begin{array}{c}\text { Internal } \\
\text { friction }\left(^{\circ}\right)\end{array}$ & $\begin{array}{c}\text { Tensile } \\
\text { strength } \\
(\mathrm{MPa})\end{array}$ & Density $\mathrm{kg} / \mathrm{m}^{3}$ \\
\hline \multirow{6}{*}{ Roof } & Medium sand & 18.13 & 7.26 & 11.49 & 2.6 & 28 & 2.4 & 2450 \\
\hline & Siltstone & 4.05 & 0.305 & 0.181 & 0.388 & 36 & 0.392 & 2400 \\
\hline & $\begin{array}{l}\text { Fine grained } \\
\text { sandstone }\end{array}$ & 3.34 & 3.05 & 3.81 & 1 & 32 & 1.2 & 2400 \\
\hline & Mudstone & 1.35 & 0.145 & 0.197 & 0.188 & 33 & 0.192 & 2360 \\
\hline & $1^{-2}$ upper coal & 1.56 & 0.122 & 0.181 & 0.171 & 31 & 0.169 & 1400 \\
\hline & Siltstone & 1.84 & 0.205 & 1.21 & 3.28 & 36 & 2.92 & 2300 \\
\hline $\begin{array}{l}\text { Coal } \\
\text { seam }\end{array}$ & $1^{-2}$ coal & 2 & 0.122 & 0.181 & 0.171 & 31 & 0.169 & 1400 \\
\hline Floor & Siltstone & 10 & 0.305 & 0.181 & 0.388 & 36 & 0.392 & 2400 \\
\hline
\end{tabular}

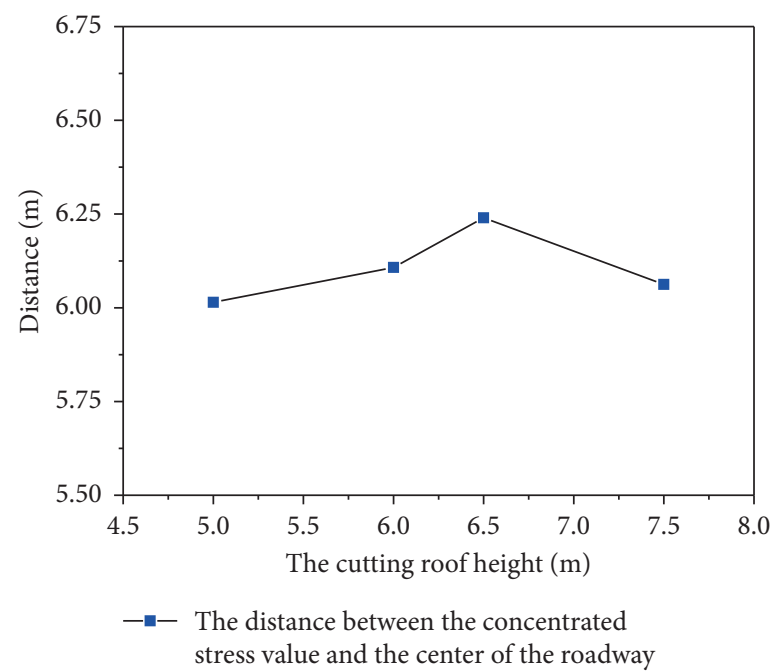

(a)

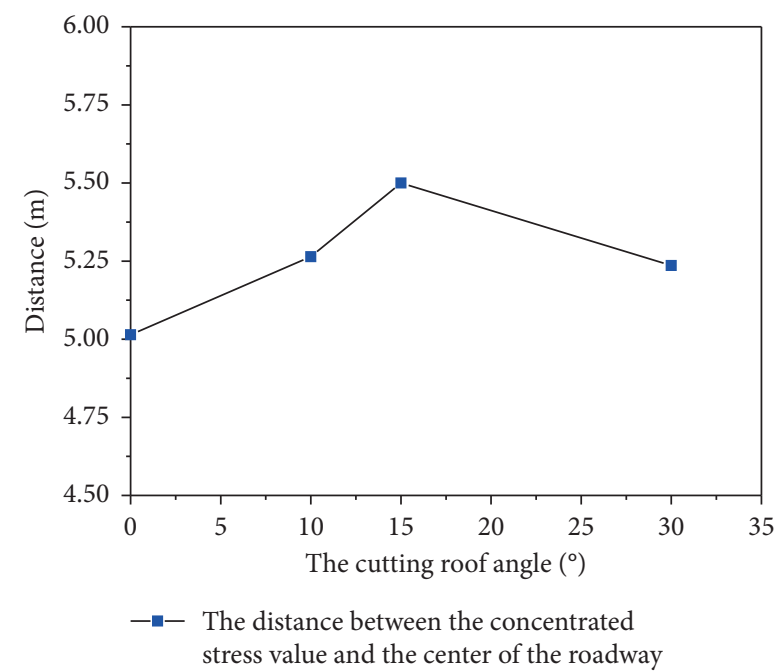

(b)

FIGURE 9: Effect analysis under different parameters: (a) cutting roof height; (b) cutting roof angle.

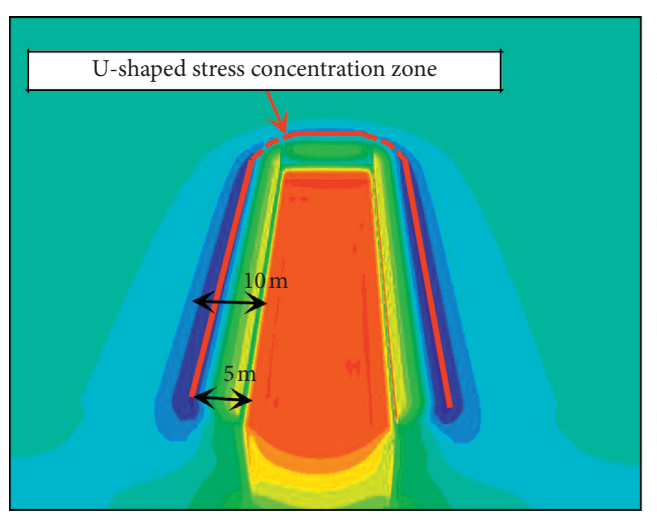

(a)

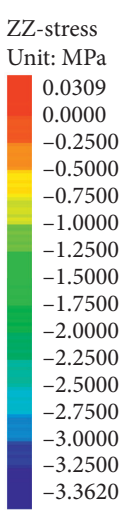

Figure 10: Continued.

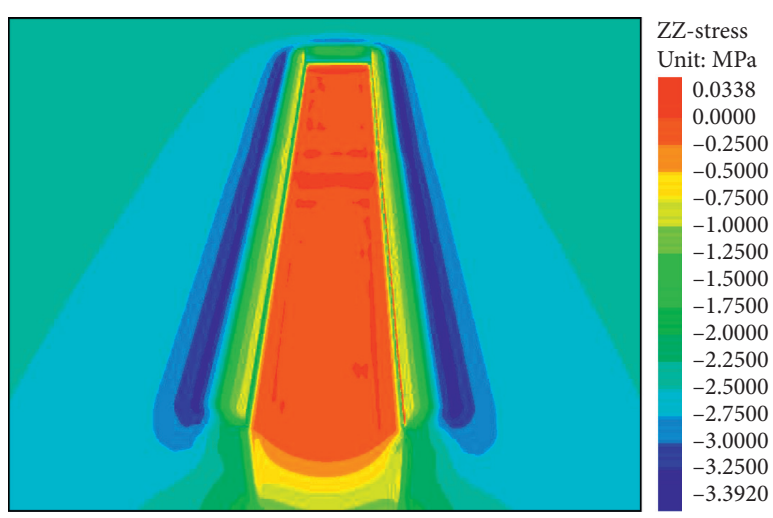

(b) 


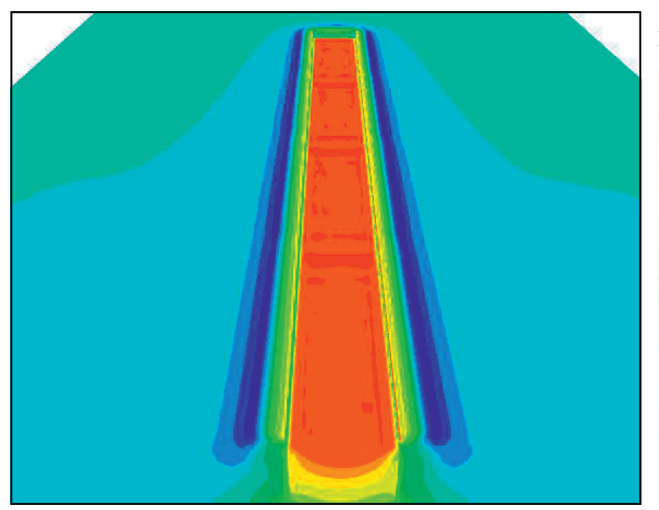

(c)

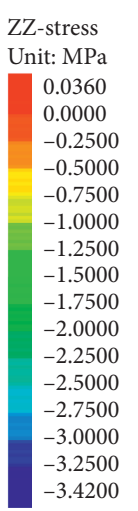

3.4200

c)

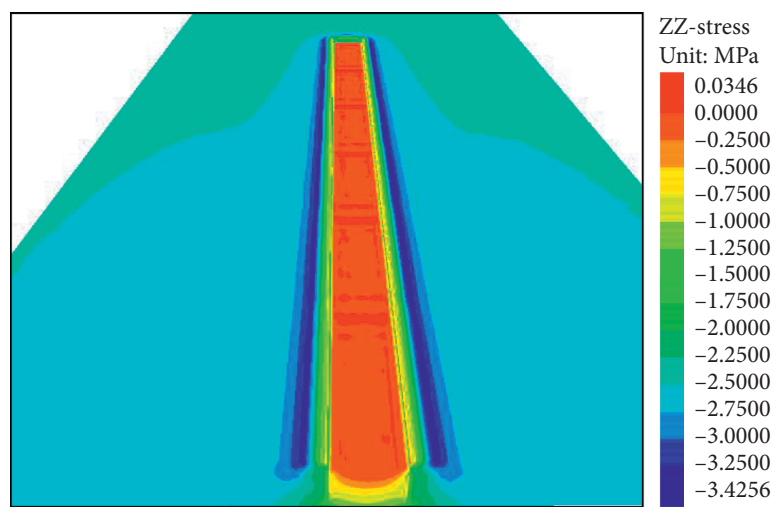

(d)

Figure 10: Vertical stress field during excavation: (a) $20 \mathrm{~m}$; (b) $40 \mathrm{~m}$; (c) $80 \mathrm{~m}$; (d) $120 \mathrm{~m}$. (unit: Pa).

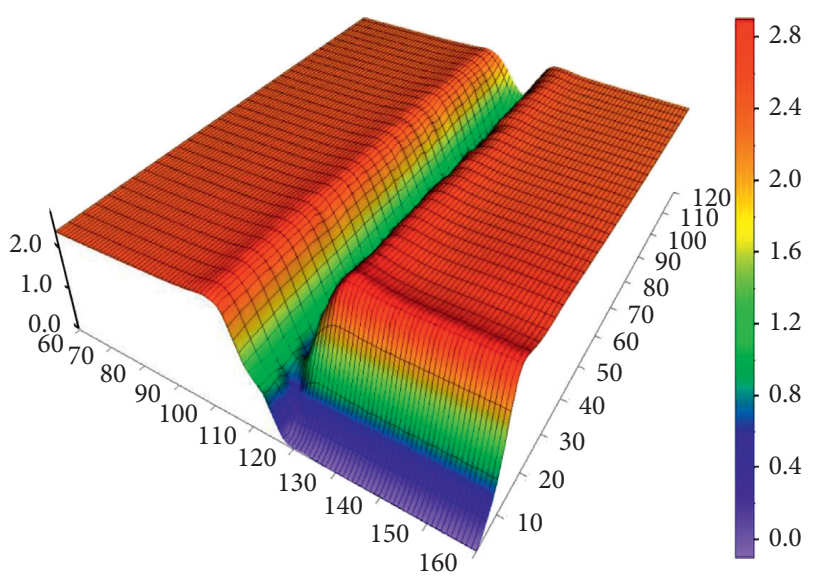

(a)

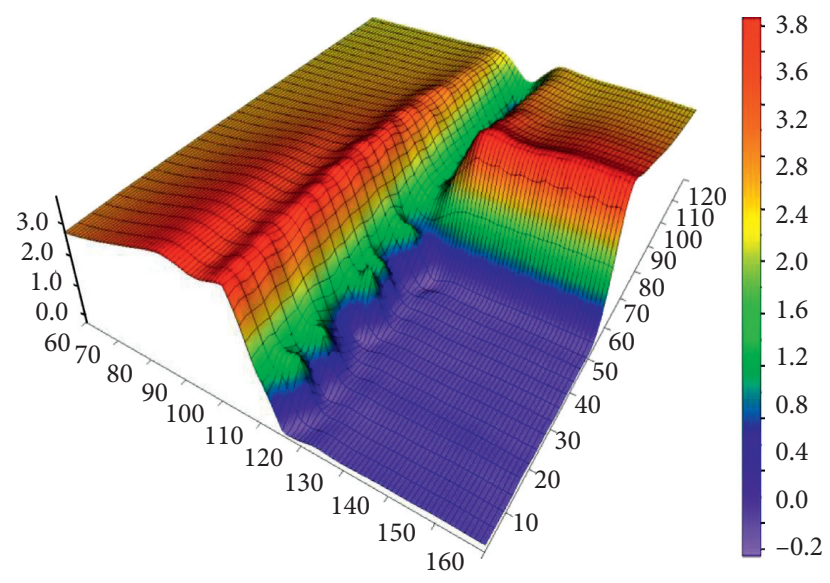

(c)

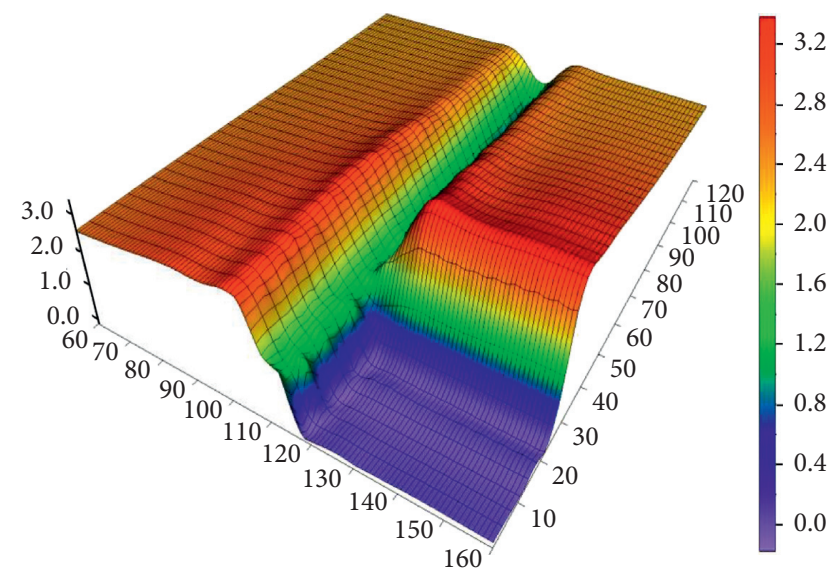

(b)

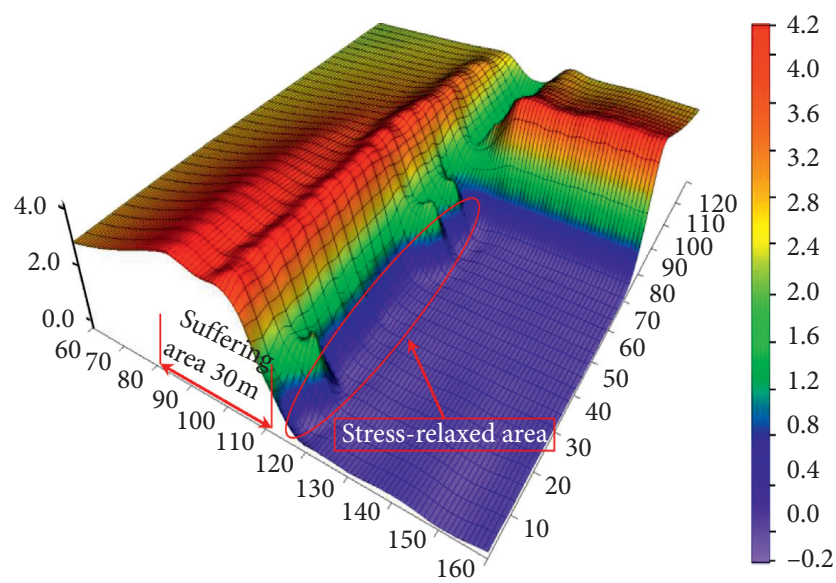

(d)

FIGURe 11: Dynamic distribution of vertical stress during mining: (a) $10 \mathrm{~m}$; (b) $30 \mathrm{~m}$; (c) $60 \mathrm{~m}$; (d) $80 \mathrm{~m}$ (unit: Pa).

5.2.3. Stress Distribution of the Next Working Face Retreating after Gob-Side Entry Retaining. The next working face is also excavated at intervals of $10 \mathrm{~m}$. It studies the dynamic stress distribution, which is above the roof of the retained roadway and stope. The numerical simulation results are shown in Figure 13. Meanwhile, the monitoring line which is shown in Figure 14 is designed for better monitoring the stress changes in the roof. Line 1 is $1.5 \mathrm{~m}$ above the incised side of 


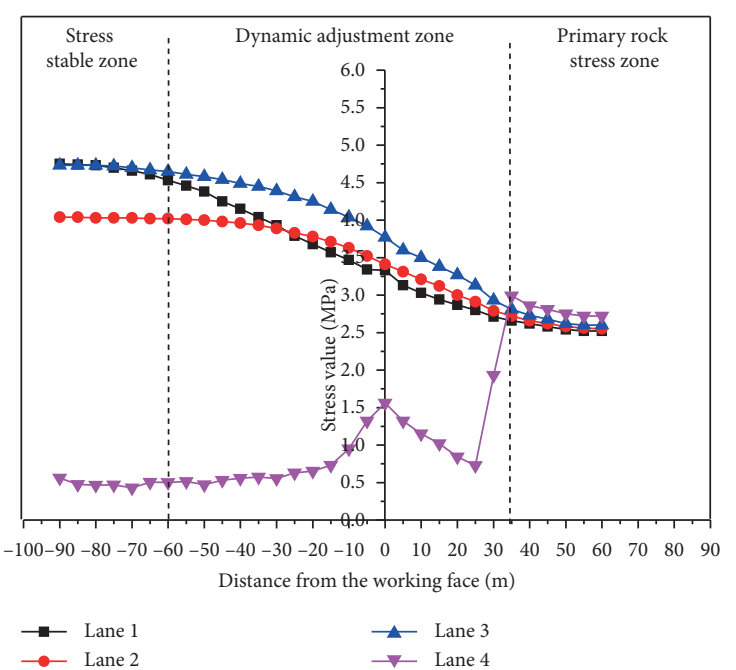

(a)

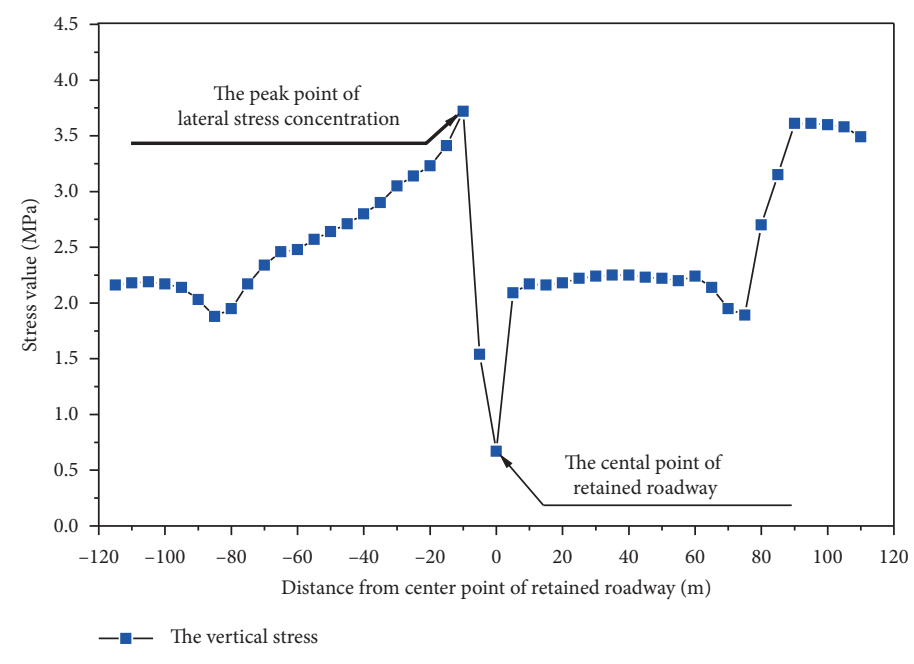

(b)

FIGURE 12: (a) Vertical stress variation of monitoring line; (b) vertical stress distribution along the strike direction of the working face.

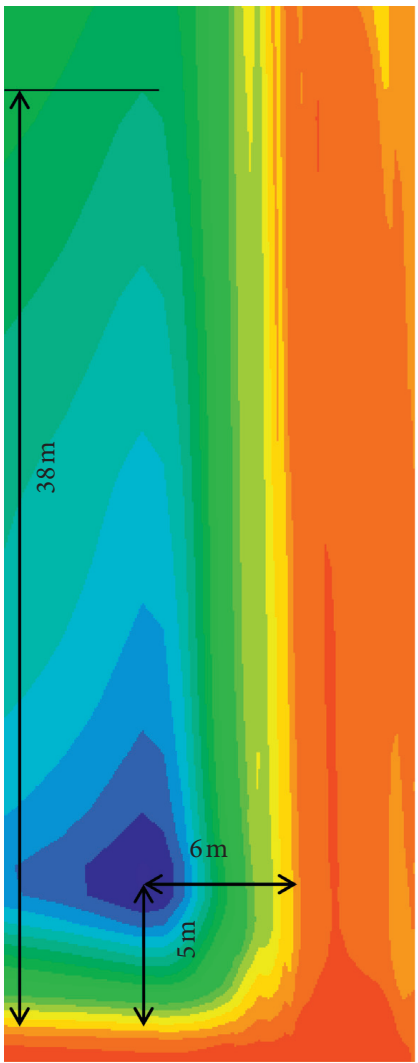

(a)

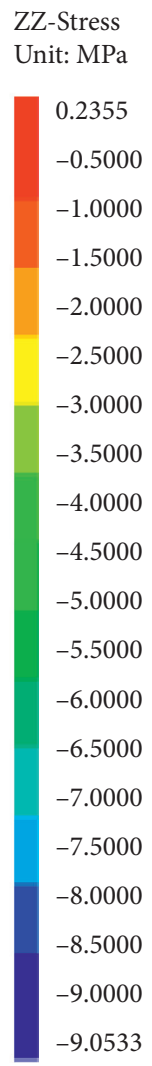

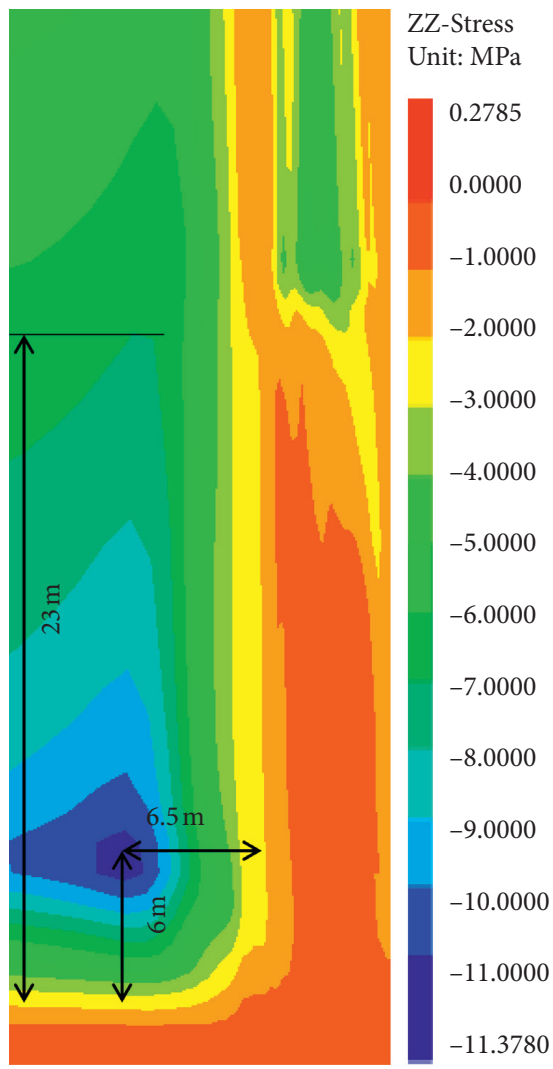

(b)

FIGURE 13: Dynamic distribution of vertical stress during second mining: (a) $40 \mathrm{~m}$ and (b) $60 \mathrm{~m}$.

the retained roadway. The distance between line 1 and line 2 is $5.5 \mathrm{~m}$. Line 3 is $1.5 \mathrm{~m}$ above the roof of the stope and it is $110.5 \mathrm{~m}$ away from the line. We monitor the changes of the leading stress when working face mining reaches $40 \mathrm{~m}$ and
$60 \mathrm{~m}$. The stress variation curve of the measured line position is shown in Figure 8.

With the excavation, the maximum concentrated stress occurs about $5 \mathrm{~m}$ in the lateral direction of the retained 


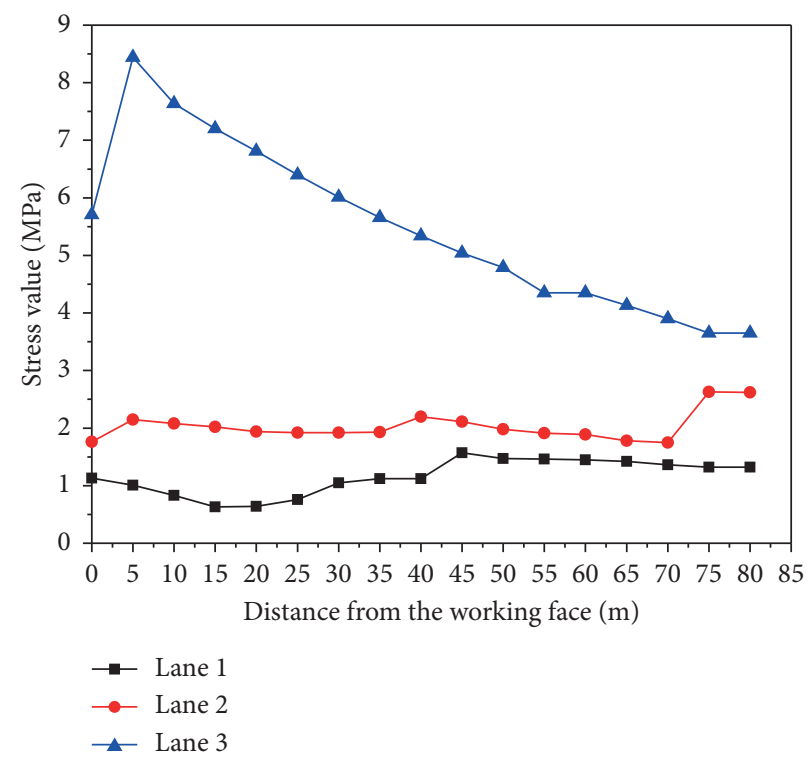

FIgURE 14: Vertical stress variation of the monitoring line position.

roadway and about $5 \mathrm{~m}$ before the working face. The concentration coefficient changes in the range of 1.6-2.02. In the process of working face advancing, the development of the area of stress concentration is negatively correlated with the change in the concentration coefficient. The maximum stress value of the roof of the reserved roadway is $2.56 \mathrm{MPa}$, which is less than the stress distribution value of the roadway after experiencing the mining on the previous working face. At this time, the stability of the surrounding rock is better, which can ensure the normal use of the retained roadway. The vertical stress trend of line 3 shows that the pressure in front of the working face is larger at a position of about $5 \mathrm{~m} \times 6 \mathrm{~m}$ square near the roadway. During the second mining, the initial support force of the hydraulic support at the working face should be adjusted to ensure normal and safe mining of the working face.

\section{In-Site Application}

The in-site application effect is monitored during the application of the GSER by RCPR. For this reason, we collect and analyze the deformation and stress of the surrounding rock of the test roadway. Field monitoring results are shown in Figure 15. The application effect is shown in Figure 16.

The monitoring results indicate that the rapid rise in the range of deformation and stress is basically consistent with the collapse process of the roof gangue. The deformation rule of surrounding rock can be divided into three stages.

In the first stage, under the influence of the caving movement of overlying strata, the deformation of the roof increased significantly, with a maximum value of $120 \mathrm{~mm}$. In the second stage, the deformation of the roof increases slowly, which is mainly influenced by the bending and subsidence of the basic roof. The increment of roof sink in this stage is $40 \mathrm{~mm}$. In the third stage, with the rebalancing of overlying strata, the surrounding rock deformation is in the fluctuation stage and finally tends to be stable. Finally, the roof sink, side shrinkage of the roadway, and floor heave are $163 \mathrm{~mm}, 129 \mathrm{~mm}$, and $72 \mathrm{~mm}$, respectively.

The surrounding rock stress development law is basically the same as the deformation law, but the surrounding rock stress can reveal the rock strata movement more accurately. Therefore, the removal of temporary support in the roadway must be based on the stress monitoring results.

After $160 \mathrm{~m}$ of lagging working face, the temporary support and gangue retaining support in the roadway were removed. The surrounding rock as a whole has no obvious deformation, and the gangue side shaping is basically flat.

\section{Discussion}

Compared with the traditional GSER, the GSER by RCPR has many advantages, such as easing the mining and replacement tension, increasing the recovery of coal resources, improving the stability of gob-side entry, reducing the gas accumulation in the upper corner of mine goaf, and eliminating the stress concentration problem caused by the legacy coal pillar.

At present, this new technology has been experimented in certain areas. The characteristics of successful application cases can be summarized as follows: (1) deep, thin seam, hard roof conditions; (2) deep well, medium thick coal seam, composite roof conditions; (3) shallow depth, medium thickness, hard roof conditions; and (4) deep, thick seam, weak roof conditions.

Although the GSER by RCPR has obvious technical and economic advantages, there are still some deficiencies. Due to the lithologic distribution and thickness variation of the roof of the roadway, the fixed slit parameters often fail to achieve the optimal slit effect for the whole roadway. This makes the lateral cantilever beam too long, which leads to poor pressure relief effect and significant stress concentration in the surrounding rock of the roadway. Therefore, in the field practice, it is necessary to adjust the cutting 


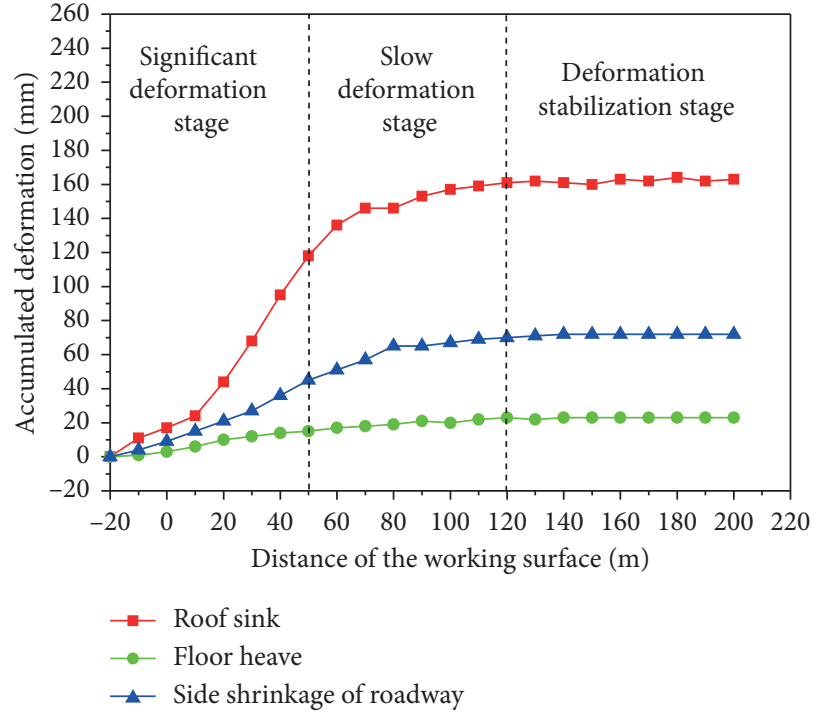

(a)

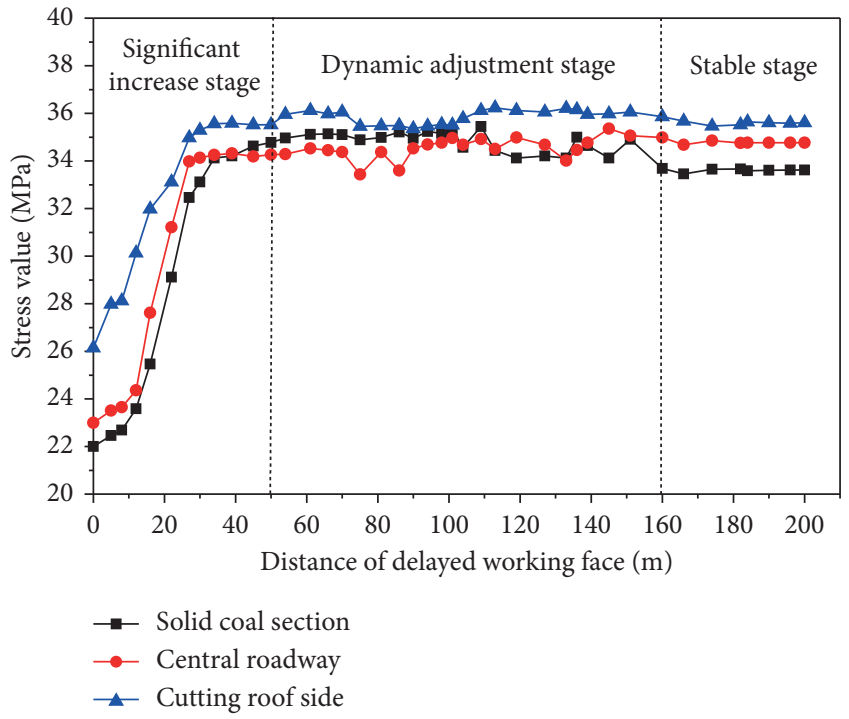

(b)

FIGURE 15: Field monitoring results: (a) accumulative deformation of surrounding rock; (b) the stress value of single hydraulic prop.

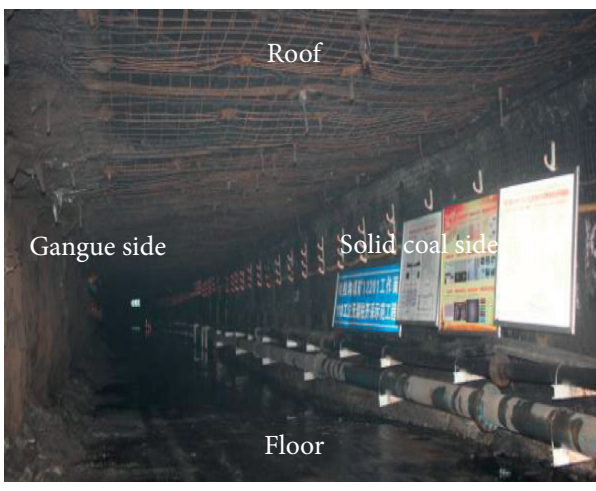

(a)

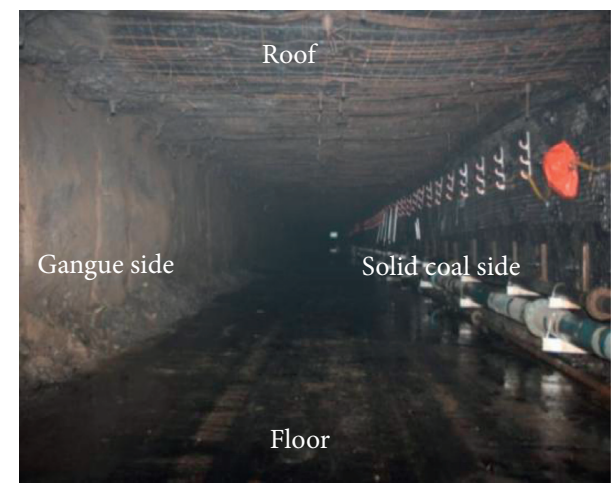

(b)

FIGURE 16: Field application effect: (a) lagging working face $100 \mathrm{~m}$; (b) lagging working face $160 \mathrm{~m}$.

parameters according to the engineering geological conditions in time to ensure the cutting effect.

At the same time, this paper mainly analyzes the pressure relief mechanism and stress evolution law of the GSER by RCPR, and the roof rock movement characteristics and their evolution law should be added later for further analysis of the action mechanism of the technology.

In addition, the current level of construction intelligence is low, so it is necessary to develop necessary intelligent equipment in the follow-up, so as to improve the construction efficiency and application effect.

\section{Conclusion}

In the paper, the stress relief mechanism of the GSER by RCPR was analyzed, and the spatiotemporal evolution law of surrounding rock of gob-side entry was revealed. The main conclusions of the study are as follows:
(1) The GSER by RCPR is based on the "Cut-roof Broken Arm Beam" theory. The core of the gob-side entry retaining by RCPR is the directional cutting roof and the CRLDS.

(2) Through the comparative analysis of the gob-side entry retaining of filling and RCPR structural mechanics models, the pressure relief mechanism of the GSER by $\mathrm{RCPR}$ is revealed. That is, by reducing the length of the lateral cantilever beam and combining with the breaking and swelling characteristics of gangue, the surrounding rock stress environment of the gob-side entry can be effectively alleviated and the controllability of surrounding rock can be improved.

(3) The numerical simulation results show that the vertical stress acting on the upper roof of gob-side entry is always in the decreasing zone. With the periodic movement of overlying strata, the periodic change of surrounding rock stress can be divided 
into three stages: significant deformation stage, dynamic adjustment stage, and stable stage; the peak stress of the side appeared $15 \mathrm{~m}$ away from the center of the roadway of the adjacent working face. However, in the second mining, the stress concentration area appears at $5-6 \mathrm{~m}$ in front of the roof heading roadway and working face, and the stress concentration value is about 1.6-2.02.

(4) Field test shows that surrounding rock tends to be stable after $100 \mathrm{~m}$ of lagging working face, and surrounding rock stress is stable in $160 \mathrm{~m}$ of lagging working face. This is different from the results of numerical analysis, which is mainly caused by the changeable field engineering geological conditions. However, the development trend of surrounding rock deformation and stress is basically the same. The final deformation of surrounding rocks is less than $170 \mathrm{~mm}$, which meets the site safety requirements. Thus, the rationality and feasibility of the GSER by RCPR are proven.

\section{Data Availability}

The data used to support the findings of this study are included within the article.

\section{Conflicts of Interest}

The authors declare that there are no conflicts of interest regarding this publication.

\section{Acknowledgments}

This work was supported by the National Natural Science Foundation of China Youth Fund (Grant nos. 51904306 and 51874311), the National Key Research and Development Plan of China (Grant no. 2016YFC0600901), the State Key Laboratory of Open Funds (Grant no. SKLGDUEK1826), the Special Fund of Basic Research and Operating (Grant no. 2009QL03), and the Yueqi Outstanding Scholar Award Program of China University of Mining and Technology, Beijing.

\section{References}

[1] Q. Wang, M. He, J. Yang, H. Gao, B. Jiang, and H. Yu, "Study of a no-pillar mining technique with automatically formed gob-side entry retaining for longwall mining in coal mines," International Journal of Rock Mechanics and Mining Sciences, vol. 110, pp. 1-8, 2018.

[2] Q. Ma, Y. Tan, Z. Zhao, Q. Xu, J. Wang, and K. Ding, "Roadside support schemes numerical simulation and field monitoring of gob-side entry retaining in soft floor and hard roof," Arabian Journal of Geosciences, vol. 11, no. 18, 2018.

[3] Z. Zhang, H. Shimada, D. Qian, and T. Sasaoka, "Application of the retained gob-side gateroad in a deep underground coalmine," International Journal of Mining, Reclamation and Environment, vol. 30, no. 5, pp. 371-389, 2016.

[4] Z. Z. Cao and Y. J. Zhou, "Research on coal pillar width in roadway driving along goaf based on the stability of key block," CMC-Computers Materials \& Continua, vol. 48, no. 2, pp. 77-90, 2015.

[5] J. G. Kan, N. Zhang, J. K. Wu, and H. Wu, "Effect of main roofs fracture position on the secondary gob-side entry retaining stability," Disaster Advances, vol. 6, no. 5, pp. 189199, 2013.

[6] C. Han, N. Zhang, J. Xue, J. Kan, and Y. Zhao, "Multiple and long-term disturbance of gob-side entry retaining by grouped roof collapse and an innovative adaptive technology," Rock Mechanics and Rock Engineering, vol. 52, no. 8, pp. 2761-2773, 2019.

[7] Y. Gao, D. Liu, X. Zhang, and M. He, "Analysis and optimization of entry stability in underground longwall mining," Sustainability, vol. 9, no. 11, p. 2079, 2017.

[8] J.-b. Bai, W.-l. Shen, G.-l. Guo, X.-y. Wang, and Y. Yu, "Roof deformation, failure characteristics, and preventive techniques of gob-side entry driving heading adjacent to the advancing working face," Rock Mechanics and Rock Engineering, vol. 48, no. 6, pp. 2447-2458, 2015.

[9] Z. Zhang, J. Bai, Y. Chen, and S. Yan, "An innovative approach for gob-side entry retaining in highly gassy fullymechanized longwall top-coal caving," International Journal of Rock Mechanics and Mining Sciences, vol. 80, pp. 1-11, 2015.

[10] C.-l. Han, N. Zhang, B.-y. Li, G.-y. Si, and X.-g. Zheng, "Pressure relief and structure stability mechanism of hard roof for gob-side entry retaining," Journal of Central South University, vol. 22, no. 11, pp. 4445-4455, 2015.

[11] C. L. Han, N. Zhang, Z. Ran, R. Gao, and H. Q. Yang, "Superposed disturbance mechanism of sequential overlying strata collapse for gob-side entry retaining and corresponding control strategies," Journal of Central South University, vol. 25, no. 9, pp. 2258-2271, 2018.

[12] H. Yang, S. Cao, Y. Li, C. Sun, and P. Guo, "Soft roof failure mechanism and supporting method for gob-side entry retaining," Minerals, vol. 5, no. 4, pp. 707-722, 2015.

[13] H. Yang, S. Cao, S. Wang, Y. Fan, S. Wang, and X. Chen, "Adaptation assessment of gob-side entry retaining based on geological factors," Engineering Geology, vol. 209, pp. 143-151, 2016.

[14] X. Li, M. Ju, Q. Yao, J. Zhou, and Z. Chong, "Numerical investigation of the effect of the location of critical rock block fracture on crack evolution in a gob-side filling wall," Rock Mechanics and Rock Engineering, vol. 49, no. 3, pp. 1041-1058, 2016.

[15] Y. Wang, Y. Gao, E. Wang, M. He, and J. Yang, "Roof deformation characteristics and preventive techniques using a novel non-pillar mining method of gob-side entry retaining by roof cutting," Energies, vol. 11, no. 3, p. 627, 2018.

[16] S. R. Islavath, D. Deb, and H. Kumar, "Numerical analysis of a longwall mining cycle and development of a composite longwall index," International Journal of Rock Mechanics and Mining Sciences, vol. 89, pp. 43-54, 2016.

[17] E. F. Salmi, M. Nazem, and M. Karakus, "Numerical analysis of a large landslide induced by coal mining subsidence," Engineering Geology, vol. 217, pp. 141-152, 2017.

[18] M. C. He, Y. B. Gao, J. Yang, Z. B. Guo, E. Y. Wang, and Y. J. Wang, "An energy-gathered roof cutting technique in nopillar mining and its impact on stress variation in surrounding rocks," Chinese Journal of Rock Mechanics and Engineering, vol. 36, no. 6, pp. 1314-1325, 2017, in Chinese.

[19] G. F. Zhang, MC. He, X. P. Yu, and Z. G. Huang, "Research on the technique of no-pillar mining with gob-side entry formed by advanced roof caving in the protective seam in Bai jiao coal 
mine," Journal of Mining and Safety Engineering, vol. 28, no. 4, pp. 511-516, 2011, in Chinese.

[20] M. He, W. Gong, J. Wang et al., "Development of a novel energy-absorbing bolt with extraordinarily large elongation and constant resistance," International Journal of Rock Mechanics and Mining Sciences, vol. 67, pp. 29-42, 2014.

[21] X.-m. Sun, Y. Zhang, D. Wang, J. Yang, H.-c. Xu, and M.-c. He, "Mechanical properties and supporting effect of CRLD bolts under static pull test conditions," International Journal of Minerals, Metallurgy, and Materials, vol. 24, no. 1, pp. 1-9, 2017.

[22] Y. B. Gao, J. Wang, H. N. Gao, J. Yang, Y. Zhang, and M. C. He, "Mine pressure distribution and surrounding rock control of gob-side entry formed by roof cutting and pressure release under the influence of faults," Chinese Journal of Rock Mechanics and Engineering, vol. 38, no. 11, pp. 2182-2193, 2019, in Chinese.

[23] S. Y. Chen, M. C. He, H. J. Wang, G. X. Yuan, F. Zhao, and Z. B. Guo, "Coordination control and stress evolution of surrounding rock of gob-side entry retaining cutting roof in deep mine," Journal of Mining \& Safety Engineering, vol. 36, no. 4, pp. 660-669, 2019, in Chinese.

[24] M. C. He, Y. J. Wang, J. Yang, Y. B. Gao, Q. Gao, and S. B. Wang, "Zonal characteristics and its influence factors of working face pressure using roof cutting and pressure-relief mining method with no pillar and roadway formed automaticly," Journal of Mining \& Safety Engineering, vol. 47, no. 6, pp. 1157-1165, 2018, in Chinese.

[25] M. C. He, Y. B. Gao, J. Yang, and W. Gong, "An innovative approach for gob-side entry retaining in thick coal seam longwall mining," Energies, vol. 10, no. 11, Article ID 1785, 2017.

[26] M. C. He, W. F. Cao, R. L. Shan, and S. L. Wang, "New blasting technology bilateral cumulative tensile explosion," Chinese Journal of Rock Mechanics and Engineering, vol. 12, pp. 2047-2051, 2003, in Chinese.

[27] F. Gao, M. G. Qian, and X. X. Miao, "Analysis of direct roof deformation under given deformation of the old roof," Chinese Journal of Rock Mechanics and Engineering, vol. 2, pp. 145-148, 2000.

[28] N. Zhang, L. Yuan, C. Han, J. Xue, and J. Kan, "Stability and deformation of surrounding rock in pillarless gob-side entry retaining," Safety Science, vol. 50, no. 4, pp. 593-599, 2012. 